\title{
Pengaruh Motivasi, Lingkungan Kerja dan Kepuasan Kerja Terhadap Kinerja Guru SMP/MTs Muhammadiyah Cabang Sawangan
}

\author{
${ }^{1}$ Soleh Sofyan*, ${ }^{2}$ Dodi Prasada, ${ }^{3}$ Irfan Rizka Akbar \\ ${ }^{1,23}$ Universitas Pamulang
}

\begin{abstract}
Alamat Surat
Email: 1'dosen02283@unpam.ac.id1, 2dosen02454@unpam.ac.id, ${ }^{3}$ dosen02461@unpam.ac.id

Article History:

Received: 10-Nopember-2020; Received in Revised: 25-Nopember-2020; Accepted: 30-Nopember-2020
\end{abstract}

\begin{abstract}
ABSTRAK
Latar belakang dan tujuan penelitian ini adalah untuk mengetahui pengaruh motivasi,lingkungan kerja dan kepuasan kerja terhadap kinerja guru SMP/Mts Muhammadiyah Cabang Sawangan baik secara parsial maupun simultan. Populasi dalam penelitian ini adalah guru yang mengajar di SMP/Mts Muhammadiyah Cabang Sawangan sebanyak 94 orang. Sampel yang digunakan adalah sampel jenuh. Metode pengumpulan data yang digunakan adalah metode kuesioner (angket) dan dokumentasi. Analisis data menggunakan bantuan software SPSS 22. Teknik analisis data yang digunakan diantaranya uji validitas dan reliabiloitass, uji asumsi klasik, uji hipotesis, analisis regresi linier sederhana dan regresi berganda. Berdasarkan hasil penelitian dari uji hipotesis secara parsial menunjukkan bahwa motivasi memiliki pengaruh sebesar 41,9\%, lingkungan kerja sebesar 31,9\% sedangkan kepuasan kerja sebesar 51,5\%. Adapun persamaan regresi linier berganda $\bar{Y}=9,750+$ $0,292 \mathrm{X} 1+0,154 \mathrm{X} 2+0,566 \mathrm{X} 3$. Dengan menggunakan bantuan SPSS 22 hasil uji hipotesis uji $\mathrm{F}$ menunjukkan F hitung $=52,703$ ( $\mathrm{F}$ table ) dengan nilai signifikansi $=0,000<0,05$ yang berarti $\mathrm{Ha}$ diterima dan Ho ditolak. Koefisien determinasi sebesar 0,637 yang bererti 63,7 \% kinerja guru SMP/Mts Muhammadiyah Cabang Sawangan dipengaruhi oleh Motivasi, Lingkungan kerja dan Kepuasan kerja, sedangkan sisanya di pengaruhi oleh variabel lain.
\end{abstract}

Kata kunci: Harga Produk, Kualitas Pelayanan, Kepuasan Pelanggan

\section{ABSTRACT}

The background and purpose of this research is to determine the effect of motivation, work environment and job satisfaction on the performance of teachers of SMP / Mts Muhammadiyah Branch of Sawangan either partially or simultaneously. The population in this study were 94 teachers who taught at SMP / Mts Muhammadiyah Sawangan Branch. The sample used is a saturated sample. The data collection method used was a questionnaire method (questionnaire) and documentation. Data analysis used SPSS 22 software. The data analysis techniques used included validity and reliability tests, classical assumption tests, hypothesis testing, simple linear regression analysis and multiple regression. Based on the results of the research, the partial hypothesis test shows that motivation has an effect of $41.9 \%$, the work environment is $31.9 \%$, while the job satisfaction is $51.5 \%$. The multiple linear regression equation $\bar{Y}=9,750+0,292 X 1+0,154 X 2+0,566$ X3. By using the help of SPSS 22 the results of the $F$ test hypothesis test showed $F$ count $=52,703$ ( $F$ table) with a significance value $=0,000<0.05$, which means that Ha is accepted and Ho is rejected. The coefficient of determination is 0.637, which means that 63.7\% of SMP / Mts Muhammadiyah Sawangan Branch teacher performance is influenced by motivation, work environment and job satisfaction, while the rest is influenced by other variables. 


\section{Keywords: Product Prices, Service Quality, Customer Satisfaction}

\section{PENDAHULUAN}

Setiap satuan pendidikan harus memahami dan menyadari pentingnya kinerja guru dalam proses pembelajaran. Kinerja seorang guru di pengaruhi oleh banyak faktor. Apabila kinerja guru rendah, maka akan berimbas pada produktivitas guru tersebut. Produktivitas guru yang rendah menunjukkan tingkat kepuasan kerja yang rendah pula, kemampuan terbaik guru dalam bekerja tidak terakomodir. Kepuasaan kerja berkaitan erat dengan sikap karyawan terhadap pekerjaanya, semakin besar tingkat kepuasaan kerja akan mendorong sikap karyawan tersebut kearah yang positif. Begitupun sebaliknya, ketidakpuasan kerja seorang karyawan akan merimbas pada sikap kerjanya ke arah negatif. Positif dan negatifnya sikap kerja seseorang berbanding lurus dengan tingkat kepuasan kerja yang dirasakan. Gaji atau upah yang diterima biasanya digunakan untuk mengukur sejauh mana tingkat kepuasan kerja seseorang, namun ini bukanlah satu - satunya variabel yang ada. Variabel lainnya yaitu lingkungan kerja, motivasi kerja dan masih banyak variabel lain yang turut berkontribusi pada kepuasan kerja dan kinerja seorang karyawan.

Muhammadiyah sebagai salah satu organisasi kemasyarakatan terbesar di Indonesia turut serta mencerdaskan kehidupan bangsa. Di bidang pendidikan, memiliki ribuan sekolah mulai dari tingkat TK sampai SMA, serta ratusan Perguruan tinggi yang tersebar di berbagai Propinsi di Indonesia. Perguruan Muhammadiyah Cabang Sawangan memiliki beberapa ranting, dan tiap ranting memiliki beberapa Sekolah mulai dari tingkat Taman Kanak - kanak sampai Sekolah Menengah Atas ( SMA ). Proses pembelajaran pada SMP/MTs Muhammadiyah di Cabang Sawangan sebagai kegiatan inti pembelajaran, (1) Proses pembelajaran masih berpusat pada guru sehingga kemampuan belajar peserta didik belum maksimal; (2) Minimnya Metode Pembelajaran yang variatif, sehingga proses pembelajaran yang menyenangkan, mengasyikan dan mencerdaskan kurang optimal; (3) Muatan belajar yang terlalu terstruktur dan sarat beban juga mengakibatkan proses pembelajaran kurang maksimal. Keadaan ini menjadikan proses belajar menjadi rutin, kurang menarik, dan kurang mampu memupuk kreativitas sehingga mempengaruhi efisiensi pendidikan.

\subsection{Kajian Pustaka \\ Motivasi}

Motivasi terbentuk dari sikap (attitude) karyawan dalam menghadapi situasi kerja di tempat kerjanya. Motivasi merupakan kondisi atau energi yang menggerakkan diri karyawan yang terarah atau tertuju untuk mencapai tujuan organisasi perusahaan. Sikap mental karyawan yang pro dan positip terhadap situasi kerja itulah yang memperkuat motivasi kerjanya untuk mencapai kinerja maksimal.

\section{Lingkungan kerja}

Lingkungan kerja merupakan salah satu komponen yang sangat penting bagi seorang karyawan dalam melakukan pekerjaanya. Lingkungan kerja meliputi semua aspek yang ada di sekitar karyawan meliputi lingkungan fisik, psikologi dan kehidupan sosial. Lingkungan Kerja menurut Rivai ( 2006: 165) adalah keseluruhan sarana dan prasarana yang ada disekitar karyawan yang sedang melakukan pekerjaan itu sendiri. Lingkungan kerja meliputi tempat kerja, fasilitas kerja dan alat bantu kerja, kebersihan, pencahayaan dan ketenangan. Jadi, lingkungan kerja yang baik akan membawa pengaruh yang positif untuk karyawan seperti semangat, gairah dan motivasi dalam bekerja.

\section{Kepuasan kerja}

Kepuasan Kerja merupakan sikap (positif) tenaga kerja terhadap pekerjaannya, yang timbul berdasarkan penilaian terhada situasi kerja. Menurut Rivai (2015:475), kepuasan kerja pada dasarnya bersifat individual. Setiap individu mempunyai tingkat kepuasan yang berbeda sesuai dengan sistem nilai yang berlaku dalam dirinya. Makin tinggi penilaian terhadap kegiatan dirasakan sesuai dengan keinginan individu, maka makin tinggi kepuasannya terhadap kegiatan tersebut. 


\section{Kinerja}

Kinerja merupakan hasil kerja secara kuantitas dan kualitas yang dicapai o;eh seorang pegawai dalam melaksanakan fungsinya sesuai dengan tanggung jawab yang diberikan kepadanya. Menurut Sedarmayanti ( 2011: 260 ) mengungkapkan bahwa kinerja merupakan terjemahan dari performance yang berarti hasil kerja seorang pekerja, sebuah proses manajemen atau suatu organisasi secara keseluruhan, dimana hasil kerja tersebut harus dapat di tunjukkan buktinya secara konkrit dan dapat diukur.

\section{METODE}

Tempat penelitian berlokasi di SMP/MTs Muhammadiyah Cabang Sawangan. Objek yang diteliti adalah para guru yang mengajar di SMP Muhammadiyah 19 Sawangan, SMP Muhammadiyah 29 Sawangan, MTs Muhammadiyah $3 \mathrm{Kp}$. Bulu dan MTs Muhammadiyah Darul Arqom yang berjumlah 94 orang. Adapun waktu penelitian dilakukan selama 3 bulan terhitung dari bulan Maret sampai bulan juni 2017. Dalam penelitian ini menggunakan metode survey. Teknik pengumpulan data-data guna keperluan analisis penelitian digunakan teknik pengumpulan data melalui kuesioner, observasi dan Studi Pustaka. Pengujian Hipotesis dilakukan dengan Uji korelasi dan regresi. Pengujian hipotesis pertama, kedua dan ketiga menggunakan uji korelasi dan regresi sederhana. Sedangkan hipotesis ke empat menggunakan uji korelasi dan regresi ganda. Pada Uji Korelasi menggunakan Uji t dan Uji F.

\section{HASIL DAN PEMBAHASAN \\ 3.1 Hasil \\ Uji Validitas}

Untuk keperluan pengujian ini dilakukan terhadap 20 guru pada perguruan Muhammadiyah Cabang Sawangan tingkat SD dan SMA yang dipilih secara acak. Instrument per-item/pertanyaan dapat dikatakan valid jika $r$ hitung lebih besar daripada $r$ tabel (pada sig $0,05, n=20, d f=18$ yaitu sebesar 0,444).

\section{Pengujian validitas variabel Motivasi $\left(\mathbf{X}_{1}\right)$}

Tabel 1 Hasil Uji Validitas Varibel Motivasi $\left(\mathrm{X}_{1}\right)$

\begin{tabular}{|c|l|c|c|c|}
\hline No & \multicolumn{1}{|c|}{ Pernyataan } & r Hitung & r Tabel & Keterangan \\
\hline 1 & Pernyataan 1 & 0,535 & 0,444 & Valid \\
\hline 2 & Pernyataan 2 & 0,519 & 0,444 & Valid \\
\hline 3 & Pernyataan 3 & 0,592 & 0,444 & Valid \\
\hline 4 & Pernyataan 4 & 0,699 & 0,444 & Valid \\
\hline 5 & Pernyataan 5 & 0,634 & 0,444 & Valid \\
\hline 6 & Pernyataan 6 & 0,682 & 0,444 & Valid \\
\hline 7 & Pernyataan 7 & 0,578 & 0,444 & Valid \\
\hline 8 & Pernyataan 8 & 0,757 & 0,444 & Valid \\
\hline 9 & Pernyataan 9 & 0,499 & 0,444 & Valid \\
\hline 10 & Pernyataan 10 & 0,482 & 0,444 & Valid \\
\hline 11 & Pernyataan 11 & 0,574 & 0,444 & Valid \\
\hline 12 & Pernyataan 12 & 0,643 & 0,444 & Valid \\
\hline 13 & Pernyataan 13 & 0,481 & 0,444 & Valid \\
\hline 14 & Pernyataan 14 & 0,686 & 0,444 & Valid \\
\hline 15 & Pernyataan 15 & 0,555 & 0,444 & Valid \\
\hline
\end{tabular}


Tabel di atas menunjukkan semua pernyataan memiliki $\mathrm{r}$ - hitung > r-tabel, sehingga dapat disimpulkan semua pernyataan yang berkaitan dengan motivasi valid.

Pengujian Validitas varibel Lingkungan Kerja.

Tabel 2 Hasil Uji Validitas Variabel Lingkungan Kerja $\left(\mathrm{X}_{2}\right)$

\begin{tabular}{|c|l|c|c|c|}
\hline No & \multicolumn{1}{|c|}{ Pernyataan } & r Hitung & r Tabel & Keterangan \\
\hline 1 & Pernyataan 1 & 0,622 & 0,444 & Valid \\
\hline 2 & Pernyataan 2 & 0,582 & 0,444 & Valid \\
\hline 3 & Pernyataan 3 & 0,820 & 0,444 & Valid \\
\hline 4 & Pernyataan 4 & 0,821 & 0,444 & Valid \\
\hline 5 & Pernyataan 5 & 0,897 & 0,444 & Valid \\
\hline 6 & Pernyataan 6 & 0,664 & 0,444 & Valid \\
\hline 7 & Pernyataan 7 & 0,738 & 0,444 & Valid \\
\hline 8 & Pernyataan 8 & 0,750 & 0,444 & Valid \\
\hline 9 & Pernyataan 9 & 0,623 & 0,444 & Valid \\
\hline 10 & Pernyataan 10 & 0,526 & 0,444 & Valid \\
\hline 11 & Pernyataan 11 & 0,598 & 0,444 & Valid \\
\hline 12 & Pernyataan 12 & 0,725 & 0,444 & Valid \\
\hline 13 & Pernyataan 13 & 0,645 & 0,444 & Valid \\
\hline 14 & Pernyataan 14 & 0,767 & 0,444 & Valid \\
\hline 15 & Pernyataan 15 & 0,579 & 0,444 & \\
\hline
\end{tabular}

Tabel di atas menunjukkan 15 butir pertanyaan memiliki $r$ - hitung lebih besar dari r-tabel sehingga dapat disimpulkan semua pernyataan yang berkaitan dengan lingkungan kerja valid.

\section{Pengujian Validitas varibel Kepuasan Kerja $\left(\mathbf{X}_{3}\right)$}

Tabel 3 Hasil Uji Validitas Varibel Kepuasan Kerja $\left(\mathrm{X}_{3}\right)$

\begin{tabular}{|c|l|c|c|c|}
\hline No & \multicolumn{1}{|c|}{ Pernyataan } & r Hitung & r Tabel & Keterangan \\
\hline 1 & Pernyataan 1 & 0,687 & 0,444 & Valid \\
\hline 2 & Pernyataan 2 & 0,530 & 0,444 & Valid \\
\hline 3 & Pernyataan 3 & 0,529 & 0,444 & Valid \\
\hline 4 & Pernyataan 4 & 0,461 & 0,444 & Valid \\
\hline 5 & Pernyataan 5 & 0,674 & 0,444 & Valid \\
\hline 6 & Pernyataan 6 & 0,466 & 0,444 & Valid \\
\hline 7 & Pernyataan 7 & 0,669 & 0,444 & Valid \\
\hline 8 & Pernyataan 8 & 0,548 & 0,444 & Valid \\
\hline 9 & Pernyataan 9 & 0,772 & 0,444 & Valid \\
\hline 10 & Pernyataan 10 & 0,738 & 0,444 & Valid \\
\hline 11 & Pernyataan 11 & 0,497 & 0,444 & Valid \\
\hline 12 & Pernyataan 12 & 0,772 & 0,444 & Valid \\
\hline 13 & Pernyataan 13 & 0,772 & 0,444 & Valid \\
\hline 14 & Pernyataan 14 & 0,595 & 0,444 & Valid \\
\hline 15 & Pernyataan 15 & 0,657 & 0,444 & Valid \\
\hline 16 & Pernyataan 16 & 0,518 & 0,444 & Valid \\
\hline
\end{tabular}

Tabel di atas menunjukkan 16 butir pernyataan memiliki r-hitung > r-tabel, sehingga dapat disimpulkan semua pernyataan yang berkaitan dengan kepuasan kerja valid. 


\section{Pengujian Validitas Variabel Kinerja Guru ( Y )}

Tabel 4 Hasil Uji Validitas Varibel Kinerja Guru (Y)

\begin{tabular}{|c|l|c|c|c|}
\hline No & \multicolumn{1}{|c|}{ Pernyataan } & r Hitung & r Tabel & Keterangan \\
\hline 1 & Pernyataan 1 & 0,624 & 0,444 & Valid \\
\hline 2 & Pernyataan 2 & 0,610 & 0,444 & Valid \\
\hline 3 & Pernyataan 3 & 0,452 & 0,444 & Valid \\
\hline 4 & Pernyataan 4 & 0,483 & 0,444 & Valid \\
\hline 5 & Pernyataan 5 & 0,754 & 0,444 & Valid \\
\hline 6 & Pernyataan 6 & 0,775 & 0,444 & Valid \\
\hline 7 & Pernyataan 7 & 0,655 & 0,444 & Valid \\
\hline 8 & Pernyataan 8 & 0,517 & 0,444 & Valid \\
\hline 9 & Pernyataan 9 & 0,531 & 0,444 & Valid \\
\hline 10 & Pernyataan 10 & 0,714 & 0,444 & Valid \\
\hline 11 & Pernyataan 11 & 0,581 & 0,444 & Valid \\
\hline 12 & Pernyataan 12 & 0,573 & 0,444 & Valid \\
\hline 13 & Pernyataan 13 & 0,710 & 0,444 & Valid \\
\hline 14 & Pernyataan 14 & 0,690 & 0,444 & Valid \\
\hline 15 & Pernyataan 15 & 0,704 & 0,444 & Valid \\
\hline
\end{tabular}

Tabel di atas menunjukkan 15 butir pernyataan memiliki r- hitung lebih besar dari r-tabel sehingga dapat disimpulkan semua pernyataan yang berkaitan dengan lingkungan kinerja valid.

\section{Uji Reliabilitas}

Hasil uji reliabilitas instrument dapat dilihat pada tabel berikut :

\section{Tabel 5 Hasil Uji Reliabilitas Data}

\begin{tabular}{|c|l|c|c|}
\hline No & \multicolumn{1}{|c|}{ Variabel } & Cronbach Alpha & Kesimpulan \\
\hline 1 & Motivasi & 0,747 & Reliable \\
\hline 2 & Lingkungan Kerja & 0,762 & Reliable \\
\hline 3 & Kepuasan Kerja & 0,751 & Reliable \\
\hline 4 & Kinerja & 0,750 & Reliable \\
\hline
\end{tabular}

\section{Sumber: Hasil Penelitian,2017}

Tabel di atas menunjukkan bahwa semua variabel reliabel karena nilai Cronbach Alpha lebih besar dari 0,6 .

\section{Deskriptip Data}

Hasil deskriptif data responden variabel yakni: Motivasi ( $\left.X_{1}\right)$, Lingkungan kerja $\left(X_{2}\right)$, Kepuasan Kerja $\left(\mathrm{X}_{3}\right)$ dan Kinerja (Y) Guru SMP/MTs Muhammadiyah Cabang Sawangan dapat digambarkan sebagai berikut:

\section{Variabel motivasi}

Hasil data rekapitulasi kuesioner dari 15 pernyataan/instrument yang berhubungan langsung dengan indikator dari Motivasi $\left(\mathrm{X}_{1}\right)$ pada tabel di atas menunjukkan yang paling diterima atau disetujui adalah indikator (1) Insentif sebesar 75,5\% dan indikator harapan sebesar 71,5\%. Sedangkan 
indikator motif yang paling rendah persentasinya yaitu sebesar 58,4\%. Secara keseluruhan indikator semua indikator motivasi dapat diterima dengan pernyataan setuju mencapai lebih dari $58,4 \%$.

\section{Variabel Lingkungan kerja}

Hasil data rekapitulasi kuesioner dari 15 pernyataan/instrument yang berhubungan langsung dengan indikator dari Lingkungan kerja $\left(\mathrm{X}_{2}\right)$ pada tabel di atas menunjukkan yang paling diterima atau disetujui adalah indikator (1) hubungan kerja sebesar 70,2\%, (2) indikator penerangan 63\%, (3) keamanan $61 \%$ dan udara $60,4 \%$. Sedangkan indikator kebisingan paling rendah persentasinya yaitu sebesar 58,9\%. Secara keseluruhan semua indikator lingkungan kerja dapat diterima dengan pernyataan setuju mencapai lebih dari $62,4 \%$.

\section{Variabel Kepuasan kerja}

Hasil data rekapitulasi kuesioner dari 16 pernyataan/instrument yang berhubungan langsung dengan indikator dari Kepuasan kerja $\left(\mathrm{X}_{3}\right)$ pada tabel di atas menunjukkan yang paling diterima atau disetujui adalah indikator (1) penghargaan sebesar 78\%, (2) indikator pekerjaan itu sendiri 73,9\%, (3) tunjangan 69,6\%. Secara keseluruhan semua indikator Kepuasan kerja dapat diterima dengan pernyataan setuju mencapai $66,6 \%$.

\section{Variabel Kinerja}

Hasil data rekapitulasi kuesioner dari 15 pernyataan/instrument yang berhubungan langsung dengan indikator dari Kinerja (Y) pada tabel di atas menunjukkan yang paling diterima atau disetujui adalah indikator (1) kualitas hasil kerja sebesar 65,6\%, (2) indikator inisiatif 58,6\%, (3) komunikasi $52,1 \%$. Sedangkan indikator ketepatan waktu dan kemampuan yang paling rendah persentasinya yaitu sebesar $51,4 \%$. Secara keseluruhan semua indikator Kinerja dapat diterima dengan pernyataan setuju mencapai lebih dari 52,1\%.

\section{Uji Asumsi Klasik}

Uji Normalitas

Berikut hasil uji normalitas dengan bantuan software SPSS 22.

Hasil Uji Normalitas

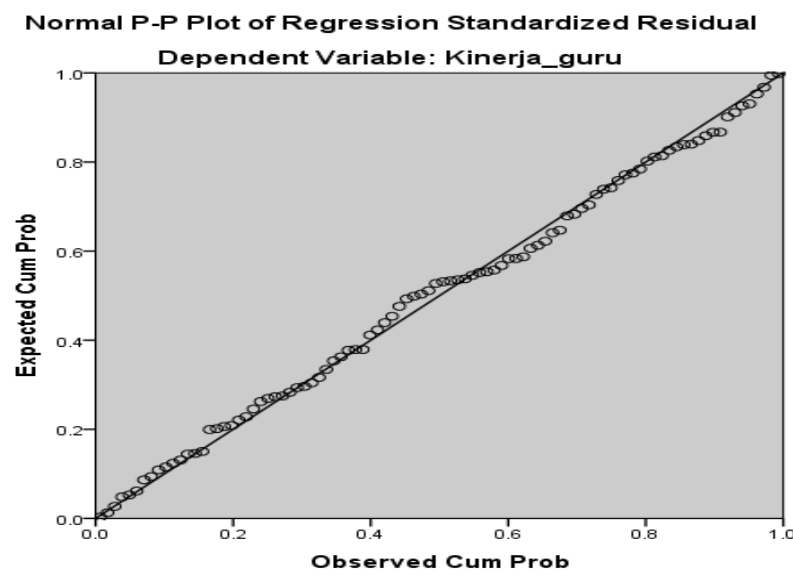

Sumber : Hasil Penelitian, 2017

Grafik di atas menunjukkan bahwa titik - titik menyebar disekitar garis sehingga dapat disimpulkan bahwa nilai residual yang dihasilkan regresi tersebut normal.

\section{Uji Multikolinieritas}

Berikut hasil uji multikolinieritas dengan bantuan software SPSS 22.

Hasil Uji Multikolinearitas - VIF(Variance Inflation Factors) 


\section{Coefficients $^{\mathrm{a}}$}

\begin{tabular}{|ll|r|r|}
\hline \multirow{2}{*}{ Model } & \multicolumn{2}{|c|}{ Collinearity Statistics } \\
\cline { 3 - 4 } & (Constant) & \multicolumn{1}{|c|}{ VIF } \\
\hline 1 & Motivasi & .615 & \\
& Lingkungan_kerja & .630 & 1.625 \\
& Kepuasan_kerja & .641 & 1.587 \\
& & & 1.559 \\
\hline
\end{tabular}

a. Dependent Variable: Kinerja_guru

Sumber: Hasil Penelitian 2017

Tabel diatas menunjukkan nilai VIF $<10$ dan besarnya nilai tolerance $>0,1$, sehingga dapat diambil kesimpulan tidak terjadi gejala multikolinearitas.

\section{Uji Heteroskadastisitas}

Berikut hasil uji Heteroskadastisitas dengan bantuan software SPSS 22

\section{Hasil Uji Heteroskadastisitas \\ Scatterplot}

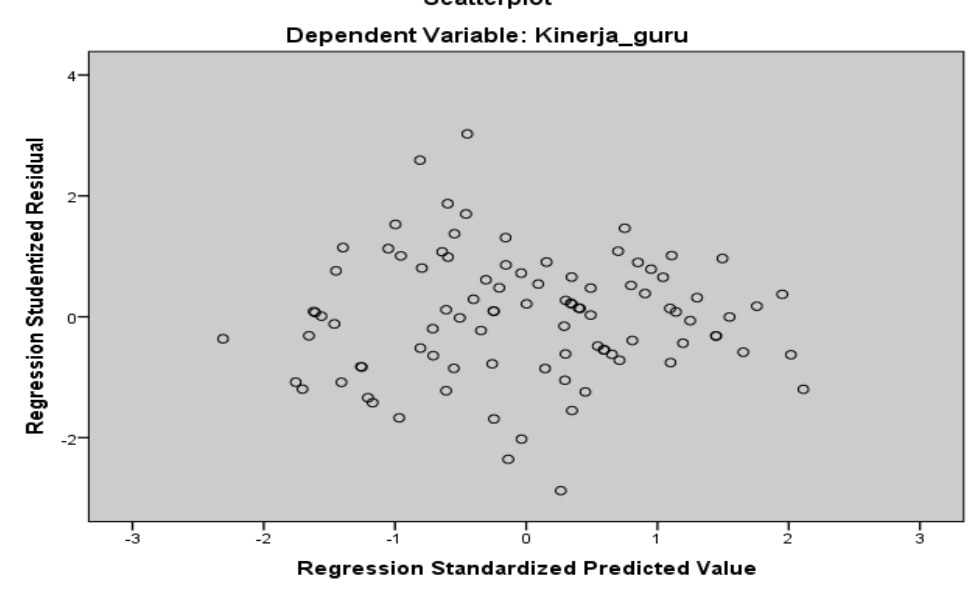

Sumber: Hasil Penelitian,2017

Gambar di atas menunjukkan bahwa titik-titik tidak membentuk pola yang jelas, dan titik-titik menyebar di atas dan di bawah angka 0 pada sumbu Y. Jadi dapat diambil kesimpulan bahwa data penelitian tidak terjadi masalah heteroskedastisitas dalam model regresi.

1. Uji Autokorelasi

Berikut Hasil Uji Autokorelasi dengan bantuan software SPSS 22.

\begin{tabular}{|l|r|r|r|r|r|}
\hline Model & Model Summary & \\
\hline 1 & R & \multicolumn{1}{|c|}{ R Square } & $\begin{array}{c}\text { Adjusted R } \\
\text { Square }\end{array}$ & $\begin{array}{c}\text { Std. Error of the } \\
\text { Estimate }\end{array}$ & Durbin-Watson \\
\hline & $.791^{\mathrm{a}}$ & .625 & .613 & 2.284 & 1.595 \\
\hline
\end{tabular}

a. Predictors: (Constant), Kepuasan_kerja, Lingkungan_kerja, Motivasi

b. Dependent Variable: Kinerja_guru

Sumber: Hasil Penelitian, 2017

Dari tabel diatas dapat kita lihat bahwa nilai DW (Durbin-Watson) berada diantara -2 sampai +2 $(1,595)$, sehingga dapat diambil kesimpulan tidak ada autokorelasi. 
1) Hasil Pengujian Hipotesis Pertama $\left(X_{1}\right.$ ke $\left.Y\right)$

a. Regresi Linier Sederhana

Pengujian hipotesis pertama menyatakan bahwa motivasi berpengaruh terhadap kinerja guru SMP Muhammadiyah cabang Sawangan.

Koefisien Regresi Linier Hipotesis Pertama

Coefficients $^{\text {a }}$

\begin{tabular}{|c|c|c|c|c|c|}
\hline \multirow[b]{2}{*}{ Model } & \multicolumn{2}{|c|}{ Unstandardized Coefficients } & $\begin{array}{c}\text { Standardized } \\
\text { Coefficients }\end{array}$ & $\mathrm{T}$ & Sig. \\
\hline & B & Std. Error & Beta & & \\
\hline 1 (Constant) & $\begin{array}{r}28.969 \\
508\end{array}$ & 4.660 & 641 & 6.217 & .000 \\
\hline
\end{tabular}

a. Dependent Variable: Kinerja_guru

Sumber: Hasil Penelitian,2017

Berdasarkan tabel diatas, maka persamaan regresi linier dalam penelitian ini adalah: $\hat{Y}=28,969+$ $0,598 \mathrm{X}_{1}$. Konstanta sebesar 28,969 menyatakan bahwa jika tidak ada kenaikan nilai dari variabel motivasi $\left(\mathrm{X}_{1}\right)$, maka nilai kinerja guru $(\mathrm{Y})$ adalah 28,969. Koefisien regresi sebesar 0,598 menyatakan bahwa setiap penambahan (karena + ) satu skor atau nilai motivasi akan memberikan peningkatan skor sebesar 0,598 .

Nilai $t_{\text {hitung }}$ untuk variabel $X_{1}=8,072$. Nilai $t_{\text {tabel }}$ dengan tingkat signifikansi $(\alpha)=0,05$ dan $\mathrm{dk}($ derajat kebebasan $)=92$ (jumlah data -2$)$, didapat nilai 1,662. Karena nilai $t_{\text {hitung }}>t_{\text {tabel }}$ atau 8,072 $>1,662$, maka $\mathrm{H}_{\mathrm{o}}$ ditolak. artinya motivasi kerja berpengaruh positif dan signifikan terhadap kinerja guru SMP/MTs Muhammadiyah Cabang Sawangan.

Koefisien Determinasi (R-Square)

Koefisien Determinasi Hipotesis pertama

Model Summary

\begin{tabular}{|c|c|c|c|c|}
\hline Model & $\mathrm{R}$ & R Square & Adjusted R Square & $\begin{array}{l}\text { Std. Error of the } \\
\text { Estimate }\end{array}$ \\
\hline 1 & $.644^{a}$ & .415 & .408 & 2.824 \\
\hline
\end{tabular}

a. Predictors: (Constant), Motivasi

Sumber : Hasil Penelitian, 2017

Koefisien determinasi sebesar 0,416 menunjukkan bahwa kemampuan variabel motivasi menjelaskan pengaruhnya terhadap kinerja sebesar 41,6\% sedangkan sisanya dipengaruhi variabel lain.

\section{Hasil Pengujian Hipotesis Kedua ( $\mathbf{X}_{2}$ ke $Y$ )}

Regresi Linier Sederhana

Pengujian hipotesis kedua menyatakan bahwa lingkungan kerja berpengaruh terhadap kinerja guru SMP Muhammadiyah cabang Sawangan.

Koefisien Regresi Linier Hipotesis Kedua

Coefficients $^{\mathrm{a}}$

\begin{tabular}{|c|c|c|c|c|c|}
\hline \multirow[b]{2}{*}{ Model } & \multicolumn{2}{|c|}{$\begin{array}{l}\text { Unstandardized } \\
\text { Coefficients }\end{array}$} & \multirow{2}{*}{$\begin{array}{c}\begin{array}{c}\text { Standardized } \\
\text { Coefficients }\end{array} \\
\text { Beta }\end{array}$} & \multirow[b]{2}{*}{$\mathrm{t}$} & \multirow[b]{2}{*}{ Sig. } \\
\hline & $\mathrm{B}$ & Std. Error & & & \\
\hline $\begin{array}{l}1 \text { (Constant) } \\
\text { Lingkungan_kerja }\end{array}$ & $\begin{array}{r}30.796 \\
.554\end{array}$ & $\begin{array}{r}5.453 \\
.084\end{array}$ & .565 & $\begin{array}{l}5.648 \\
6.561\end{array}$ & $\begin{array}{l}.000 \\
.000\end{array}$ \\
\hline
\end{tabular}

a. Dependent Variable: Kinerja_guru 


\section{Sumber : Hasil Penelitian, 2017}

Berdasarkan tabel diatas, maka persamaan regresi linier dalam penelitian ini adalah: $\hat{Y}=30,769+$ $0,554 \mathrm{X}_{2}$ Konstanta sebesar 30,769 menyatakan bahwa jika tidak ada kenaikan nilai dari variabel Lingkungan kerja $\left(\mathrm{X}_{2}\right)$, maka nilai kinerja guru (Y) adalah 30,769. Koefisien regresi sebesar 0,554 menyatakan bahwa setiap penambahan $(k a r e n a+)$ satu skor atau nilai motivasi akan memberikan peningkatan skor sebesar 0,554. Nilai thitung untuk variabel $X_{2}=6,561$. Nilai tabel dengan tingkat signifikansi $(\alpha)=0,05 \mathrm{dan} \mathrm{dk}($ derajat kebebasan $)=92($ jumlah data -2$)$, didapat nilai 1,662. Karena nilai $t_{\text {hitung }}>\mathrm{t}_{\text {tabel }}$ atau 6,561 >1,662, maka $\mathrm{H}_{\mathrm{o}}$ ditolak. Berdasarkan hasil yang diperoleh maka menolak $\mathrm{H}_{0}$ dan menerima $\mathrm{H}_{2}$ untuk variabel lingkungan kerja, artinya secara parsial variabel lingkungan kerja berpengaruh secara positif dan signifikan terhadap kinerja guru SMP/MTs Muhammadiyah Cabang Sawangan.

\section{Koefisien Determinasi (R-Square)}

Koefisien Determinasi Hipotesis Kedua

\section{Model Summary}

\begin{tabular}{|l|r|r|r|r|}
\hline Model & $\mathrm{R}$ & R Square & Adjusted R Square & $\begin{array}{c}\text { Std. Error of the } \\
\text { Estimate }\end{array}$ \\
\hline 1 & $.565^{\mathrm{a}}$ & .319 & .311 & 3.047 \\
\hline
\end{tabular}

a. Predictors: (Constant), Lingkungan_kerja

Sumber : Hasil Penelitian, 2017

Berdasarkan tabel diatas, diperoleh nilai koefisien determinasi sebesar 0,319. Hal ini menunjukkan bahwa kemampuan variabel motivasi menjelaskan pengaruhnya terhadap variabel kinerja guru SMP/MTs Muhammadiyah cabang Sawangan sebesar 31,9 \%. Sedangkan sisanya sebesar $68,1 \%$ merupakan pengaruh dari variabel bebas lain.

\section{Hasil Pengujian Hipotesis Ketiga ( $\mathrm{X}_{3}$ ke $\mathrm{Y}$ )}

Regresi Linier Sederhana

Koefisien Regresi Linier Hipotesis Ketiga

Coefficients $^{\mathrm{a}}$

\begin{tabular}{|c|c|c|c|c|c|}
\hline \multirow[b]{2}{*}{ Model } & \multicolumn{2}{|c|}{ Unstandardized Coefficients } & \multirow{2}{*}{\begin{tabular}{|c}
$\begin{array}{c}\text { Standardized } \\
\text { Coefficients }\end{array}$ \\
Beta \\
\end{tabular}} & \multirow[b]{2}{*}{$\mathrm{t}$} & \multirow[b]{2}{*}{ Sig. } \\
\hline & $\mathrm{B}$ & Std. Error & & & \\
\hline $\begin{array}{ll}1 \text { (Constant) } \\
\text { Kepuasan_kerja }\end{array}$ & $\begin{array}{r}21.537 \\
.665\end{array}$ & $\begin{array}{r}4.541 \\
.067\end{array}$ & .719 & $\begin{array}{l}4.743 \\
9.921\end{array}$ & $\begin{array}{l}.000 \\
.000\end{array}$ \\
\hline
\end{tabular}

a. Dependent Variable: Kinerja_guru

Sumber : Hasil Penelitian, 2017

Berdasarkan tabel diatas, maka persamaan regresi linier dalam penelitian ini adalah: $\hat{\mathrm{Y}}=$ $21,537+0,665 \mathrm{X}_{3}$. Konstanta sebesar 21,537 menyatakan bahwa jika tidak ada kenaikan nilai dari variabel Kepuasan kerja $\left(\mathrm{X}_{3}\right)$, maka nilai kinerja guru $(\mathrm{Y})$ adalah 21,537. Koefisien regresi sebesar 0,665 menyatakan bahwa setiap penambahan (karena +) satu skor atau nilai motivasi akan memberikan peningkatan skor sebesar 0,665 . Nilai thitung untuk variabel $X_{3}=9,931$. Nilai tabel dengan tingkat signifikansi $(\alpha)=0,05 \mathrm{dan} \mathrm{dk}($ derajat kebebasan $)=92$ (jumlah data -2 ), didapat nilai 1,662. Karena nilai $t_{\text {hitung }}>t_{\text {tabel }}$ atau 9,931 $>1,662$, maka $H_{o}$ ditolak. Berdasarkan hasil yang diperoleh maka menolak $\mathrm{H}_{0}$ dan menerima $\mathrm{H}_{3}$ untuk variabel kepuasan kerja, artinya secara parsial variabel kepuasan 
kerja berpengaruh secara positif dan signifikan terhadap kinerja guru SMP/MTs Muhammadiyah Cabang Sawangan.

Koefisien Determinasi (R-Square)

Koefisien Determinasi Hipotesis ketiga

Model Summary

\begin{tabular}{|l|r|r|r|r|}
\hline Model & R & R Square & Adjusted R Square & Std. Error of the Estimate \\
\hline 1 & $.719^{\mathrm{a}}$ & .517 & .512 & 2.566 \\
\hline
\end{tabular}

a. Predictors: (Constant), Kepuasan_kerja

Sumber : Hasil Penelitian, 2017

Berdasarkan tabel diatas, diperoleh nilai koefisien determinasi sebesar 0,517. Hal ini menunjukkan bahwa kemampuan variabel kepuasan kerja menjelaskan pengaruhnya terhadap variabel kinerja guru SMP/MTs Muhammadiyah cabang Sawangan sebesar 51,7 \%. Sedangkan sisanya sebesar 48,3\% merupakan pengaruh dari variabel bebas lain.

Hasil Pengujian Hipotesis Keempat $\left(\mathrm{X}_{1}, \mathrm{X}_{2}, \mathrm{X}_{3} \mathrm{ke} \mathrm{Y}\right)$

Regresi Berganda Hipotesis keempat

Koefisien Regresi Linier Hipotesis Keempat

\section{Coefficients $^{\mathrm{a}}$}

\begin{tabular}{|c|c|c|c|c|c|c|}
\hline \multirow{2}{*}{\multicolumn{2}{|c|}{ Model }} & \multicolumn{2}{|c|}{$\begin{array}{c}\text { Unstandardized } \\
\text { Coefficients }\end{array}$} & \multirow{2}{*}{$\begin{array}{c}\begin{array}{c}\text { Standardized } \\
\text { Coefficients }\end{array} \\
\text { Beta } \\
\end{array}$} & \multirow[b]{2}{*}{$\mathrm{T}$} & \multirow[b]{2}{*}{ Sig. } \\
\hline & & $\mathrm{B}$ & Std. Error & & & \\
\hline 1 & (Constant) & 9.291 & 4.796 & & 1.937 & .056 \\
\hline & Motivasi & .285 & .076 & .307 & 3.736 & .000 \\
\hline & Lingkungan_kerja & .147 & .080 & .149 & 1.837 & .070 \\
\hline & Kepuasan_kerja & .441 & .074 & .477 & 5.924 & .000 \\
\hline
\end{tabular}

a. Dependent Variable: Kinerja_guru

Sumber : Hasil Penelitian, 2017

Berdasarkan tabel di atas, maka persamaan regresi berganda dalam penelitian ini adalah: $\hat{\mathrm{Y}}=9,291$ $+0,285 \mathrm{X}_{1}+0,147 \mathrm{X}_{2}+0,441 \mathrm{X}_{3}$ Nilai konstanta sebesar 9,291 artinya nilai kinerja tanpa adanya motivasi, lingkungan kerja dan kepuasan sebesar 9,291.

\section{Koefisien Determinasi (R-Square)}

\section{Koefisien Determinasi Hipotesis Keempat}

\section{Model Summary}

\begin{tabular}{|l|r|r|r|r|}
\hline Model & R & \multicolumn{1}{|c|}{ R Square } & Adjusted R Square & Std. Error of the Estimate \\
\hline 1 & $.791^{\mathrm{a}}$ & .625 & .613 & 2.284 \\
\hline
\end{tabular}

a. Predictors: (Constant), Kepuasan_kerja, Lingkungan_kerja, Motivasi

Sumber : Hasil Penelitian, 2017

Berdasarkan tabel di atas nilai koefisien determinasi $\left(\mathrm{R}^{2}\right)=0,625$. artinya kemampuan variabel motivasi, lingkungan keja dan kepuasan kerja menjelaskan pengaruhnya terhadap kinerja guru SMP/MTs Muhammadiyah cabang Sawangan sebesar 62,5\%. Sedangkan sisanya sebesar 37,5\% dipengaruhi variabel lain yang tidak diteliti dalam penelitian ini. 
Uji F

Hasil Uji $\mathrm{F}_{\text {tes }}$ Hipotesis ke empat

ANOVA ${ }^{a}$

\begin{tabular}{|l|r|r|r|r|r|}
\hline Model & Sum of Squares & Df & Mean Square & F & Sig. \\
\hline 1 Regression & 783.812 & 3 & 261.271 & 50.065 & $.000^{\mathrm{b}}$ \\
& 469.677 & 90 & 5.219 & & \\
Residual & 1253.489 & 93 & & & \\
Total & & & & \\
\hline
\end{tabular}

a. Dependent Variable: Kinerja_guru

b. Predictors: (Constant), Kepuasan_kerja, Lingkungan_kerja, Motivasi

Sumber : Hasil Penelitian, 2017

Dari tabel hasil uji anova atau $\mathrm{F}_{\text {tes }}$, ternyata didapat $\mathrm{F}_{\text {hitung }}$ sebesar 50,065 dengan tingkat signifikansi 0,000 karena probabilitas $(0,000)$ jauh lebih kecil dari 0,05, maka model regresi dapat dipakai untuk memprediksi kinerja guru. Dengan df pembilang $(\mathrm{n} 1)=3$, dan df penyebut $(\mathrm{n} 2)=90$, dan $\alpha=0,05$ didapat $F_{\text {tabel }}=2,71$. Ternyata $F_{\text {hitung }}>F_{\text {tabel, }}$ atau 50,065 $>2,71$, maka signifikan. Dapat disimpulkan bahwa secara simultan motivasi, lingkungan kerja dan kepuasan kerja berpengaruh positif dan signifikan terhadap kinerja guru SMP/MTs Muhammadiyah cabang Sawangan.

\section{KESIMPULAN}

\subsection{Kesimpulan}

Besarnya pengaruh secara simultan antara variabel motivasi (X1), Lingkungan kerja (X2) dan Kepuasan kerja (X3) terhadap kinerja guru SMP/MTs Muhammadiyah cabang Sawangan tergolong kuat. Sedangkan kontribusi secara bersama-sama (simultan) variabel X1,X2 dan X3 terhadap Y= R2 $\mathrm{x} 100 \%$ atau $0,625 \times 100 \%=62,5 \%$ sedangkan sisanya sebesar 37,5\% merupakan pengaruh dari variabel bebas lain yang tidak diteliti dalam penelitian ini. Kemudian mengenai naik turunnya atau besar kecilnya kinerja guru dapat diprediksi melalui persamaan $\hat{Y}=9,291+0,285 X 1+0,147 X 2+$ $0,441 \mathrm{X} 3$

\subsection{Saran}

Dari kesimpulan di atas, untuk mengantisipasi hal-hal tersebut dan untuk mencapai maksud dan tujuan peningkatan kinerja guru SMP/MTs Muhammadiyah Cabang Sawangan, maka disarankan sebagai berikut

a. Kepala sekolah mengupayakan peningkatan tunjangan kesejahteraan bagi guru- guru secara adil dan transparan.

b. Pimpinan dan steak holder senantiasa meningkatkan fasilitas sarana dan prasarana untuk kelancaran kegiatan belajar dan mengajar.

c. Kepala sekolah senantiasa meningkatkan kemampuan para guru dengan cara, memberikan kesempatan untuk mengikuti: workshop, seminar, Uji Kompetensi Guru, atau melanjutkan pendidikan yang lebih tinggi baik formal maupun informal, sehingga guru dapat meningkatkan pengetahuan dan ketrampilan dalam mengajar.

\section{DAFTAR PUSTAKA}

Hamali, Arif Yusup. Pemahaman Manajemen Sumber Daya Manusia, CAPS, Yogyakarta, 2017.

Mangkunegara, A.A. Anwar Prabu. Evaluasi Kinerja Sumber Daya Manusia Perusahaan. PT. Refika Aditama, Bandung, 2006. 2009. Evaluasi Kinerja Sumber Daya Manusia Perusahaan. PT. Refika Aditama, Bandung,2009. 
Nitisemito, Alex S. Manajemen Personalian: Manajemen Sumber Daya Manusai. Edisi 3, Ghaila Indonesia,Jakarta,2008.

Rivai, Veithzal. Manajemen Sumber Daya Manusia untuk Perusahaan: dari Teori ke Praktik: PT. Raja Grafindo Persada, Jakarta,2006. . Manajemen Sumber Daya Manusia untuk Perusahaan: dari Teori ke Praktik: PT. Raja Grafindo Persada,Jakarta,2015.

Sarwoto. Dasar-Dasar Organisasi dan Manajemen. Ghalia, Jakarta,2011.

Sedarmayanti. Sumber Daya Manusia dan Produktivitas Kerja.Mandar Maju, Bandung,2011.

Sugiono. Metode Penelitian Administrasi . Alfhabetha, Bandung, 2012.

Sunarsi, D. (2018). Pengembangan Sumber Daya Manusia Strategik \& Karakterisrik Sistem Pendukungnya : Sebuah Tinjauan. Jurnal Ilmiah MEA (Manajemen, Ekonomi, \& Akuntansi), 2(3), 178 - 194.

Sunarsi, D. (2019). Seminar Sumber Daya Manusia. Tangerang Selatan: Unpam Press

Sunarsi, D. (2018). Buku Ajar: Seminar Perencanaan Sumber Daya Manusia. Tangerang Selatan: Asmoro Mediatama

Sunyoto, Danang. Manajemen Sumber Daya Manusia. CAPS, Yogyakarta, 2013.

Wijoyo, H., Handoko, A. L., Santamoko, R., \& Sunarsi, D. (2020). Strategy Model for Character Education through Digital Media for Courses and Training Participants. E-Prosiding Pascasarjana Universitas Negeri Gorontalo, 1-8.

Wijoyo, H. (2020). Analisis Pengendalian Internal Dalam Pemberian Kredit Pada PT Bank Perkreditan Rakyat (BPR) Indomitra Mandiri. TIN: Terapan Informatika Nusantara, 1(4), 157-162.

Wijoyo, H. (2018). Analisis Pengakuan Pendapatan dan Beban Kontrak Konstruksi Pada PT. Wahana Tata Riau. Jurnal Ilmu Komputer dan Bisnis, 9(2), 2034-2043.

. Penelitian Sumber Daya Manusia, Teori, Kuesioner, Alat Statistik dan Contoh Rise . CAPS, Yogyakarta,2015.

Yuangga, K. D., \& Sunarsi, D. (2018). The Influence of Procrastination and Low Time Management on Student Self Efficacy (at MA Soebono Mantofani). PINISI Discretion Review, 2(1), 8592. 